\title{
A mass more ordinary
}

\author{
Joy C Edlin, Maryam Alfa-Wali, Amanda Bond
}

Department of UGI Surgery, Kingston Hospital, Kingston Upon Thames, UK

\section{Correspondence to} Joy C Edlin, joy.edlin@nhs.net

Accepted 6 April 2015

\section{CrossMark}

To cite: Edlin JC, AlfaWali $\mathrm{M}$, Bond A. BMJ Case Rep Published online: [please include Day Month Year] doi:10.1136/bcr-2015209409

\section{DESCRIPTION}

An 88-year-old woman presented with sudden onset sharp upper abdominal pain associated with anorexia, vomiting and weight loss. Examination revealed a tender palpable mass in the epigastrium without any abnormal blood tests. A CT scan showed a $12 \mathrm{~cm}$ cystic mass in the epigastrium with the gallbladder not identified, and separate from the liver and pancreas (figure 1). Ultrasound confirmed the cystic lesion as the gallbladder with sludge. A cholecystostomy was initially performed, draining $600 \mathrm{~mL}$ bile-stained and blood-stained fluid. The patient subsequently underwent a laparoscopic cholecystectomy 6 weeks later without any complications. Histopathology showed chronic inflammatory changes of cholecystitis.

Intra-abdominal cystic structures can have several origins, including gallbladder, biliary tree, pancreas, kidney, adrenal, omentum, mesentery, appendix vermiformis and ovaries. ${ }^{1}$ The upper limit of gallbladder volume is usually $60 \mathrm{~mL}$. Moderately enlarged gallbladders containing $200-300 \mathrm{~mL}$ are encountered in surgical practice. Giant gallbladders have been reported to contain between $1.5 \mathrm{~L}$ and $5 \mathrm{~L}$ with dimensions from $18 \times 4 \mathrm{~cm}$ to $43 \times 21 \mathrm{~cm}^{2}$

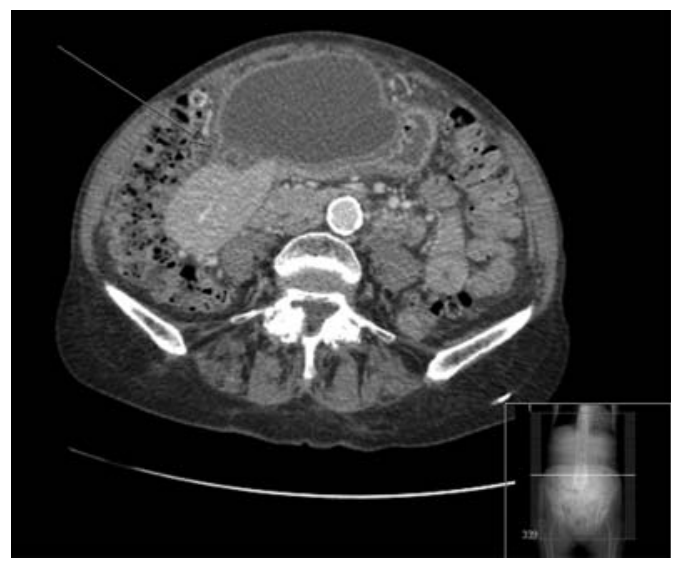

Figure 1 CT scan with axial view of the abdomen showing a $12 \mathrm{~cm}$ cystic mass in the epigastrium, separate from the liver and pancreas. The gallbladder is not clearly identified.
Their aetiology includes congenital, gallstones or sludge or tumour or a 'wandering' gallbladder, where the gallbladder is attached to surrounding structures only by the cystic duct and its mesentery, making it prone to torsion. Irrespective, the drainage of bile is impaired and the gallbladder distended.

Large or giant gallbladders require special surgical consideration. In our case, the gallbladder was successfully drained via cholecystostomy and subsequently removed by a laparoscopic cholecystectomy. Some authors report open cholecystectomy without preoperative drainage, taking special consideration of adhesions to adjacent structures. ${ }^{2} 3$

\section{Learning points}

- Cystic lesions found on imaging, with red flag symptoms, as in the case of our patient, can be from malignant or benign causes.

- The aetiology of large or giant gallbladders includes congenital, gallstones or sludge, or tumour or a 'wandering' gallbladder, the latter three causes leading to impaired drainage of bile and a gradual enlargement of the gallbladder.

- Large or giant gallbladders require special surgical consideration.

Contributors JCE, MA-W and $A B$ all contributed to the preparation of this article.

Competing interests None declared.

Patient consent Obtained.

Provenance and peer review Not commissioned; externally peer reviewed.

\section{REFERENCES}

1 Wootton-Gorges SL, Thomas KB, Harned RK, et al. Giant cystic abdominal masses in children. Pediatr Radiol 2005;35:1277-88.

2 Kuznetsov AV, Borodach AV, Fedin EN, et al. Giant gallbladder: a case report and review of literature. Int I Surg Case Rep 2014:5:673-6.

3 Maeda Y, Setoguchi T, Yoshida T, et al. A giant gallbladder. Gastroenterol Jpn 1979;14:621-4.

Copyright 2015 BMJ Publishing Group. All rights reserved. For permission to reuse any of this content visit http://group.bmi.com/group/rights-licensing/permissions.

BMJ Case Report Fellows may re-use this article for personal use and teaching without any further permission.

Become a Fellow of BMJ Case Reports today and you can:

- Submit as many cases as you like

- Enjoy fast sympathetic peer review and rapid publication of accepted articles

- Access all the published articles

- Re-use any of the published material for personal use and teaching without further permission

For information on Institutional Fellowships contact consortiasales@bmjgroup.com

Visit casereports.bmj.com for more articles like this and to become a Fellow 